primary union, but the bronchitis gave us much alarm and threatened more than once to carry off the patient before she could be allowed to get up; otherwise she made an excellent recovery, and although not wearing a truss the hernia did not again come down during the remainder of her life, which was terminated by the bronchitis three months after the operation. Although her age was so great she was thin and wiry, and had she not been a sufferer from bronchitis would no doubt have survived for several years. From the matted and adherent state of the omentum the hernia must have existed some considerable period of time before it was noticed.

Chetwynd-road, Highgate, N.W.

\section{THE TREATMENT OF OXYURIS VERMICULARIS.}

By B. H. Nicholson, M.B., C.M. Edix.,

LATE RESIDENT SURGEON, ESSEX AND COLCHESTER HOSPITAL.

THREADWORMS are one of the commonest and yet one of the most troublesome ailments we are brought into contact with in practice and unless treatment is firmly and properly carried out, relapses are certain every few months, often producing reflexly epilepsy, chorea, convulsions, insomnia and many other debilitating and distressing troubles. First, one or two remarks as to the habitat of the nematode. The ova may develop in the large intestine of the host, or after irritation and scratching of the anus the ova may be carried to the mouth of the patient, swallowed and then the embryo may be liberated from its cell wall by the action of the gastric juice and then gradually become a mature oxyuris and inhabit the cæcum and large intestine. By the time the female oxyuris reaches the sigmoid flexure and rectum the uterus is full of ova which may be born into the intestinal tract or liberated on the expulsion of the oxyuris from the anus.

Treatment. - The child should be bathed twice daily, the underclothing changed frequently, a draw sheet put below the patient at night, the nails kept short, the fingers dipped frequently in an infusion of quassia, and the anus smeared night and morning with an ointment composed of nitrate of mercury with a small quantity of extract of quassia added. The condition of the bowels should be attended to. Mercury with chalk and rhubarb and soda powder should be prescribed to secure daily evacuation. Now santonin must be given every other night for a week and if taken longer santoninism must be guarded against-viz., tenesmus, spasms, yellow vision, hæmorrhages and red-yellowish urine. Attention should be paid to the bile secretion, the great antiseptic of the intestinal tract. The endeavour should be to increase peristalsis and diminish the secretion of mucus by giving as a tonic citrate of iron and strychnine in moderate doses after food. I have lately been using with great benefit extract of quassia made into a suppository with cacao butter (one to three grains ) ; these suppositories are easily introdnced at night and children do not object to them. Injections are disliked by children and it is difficult to get the mother or nurses to take the necessary trouble. An injection of menthol (one grain) dissolved in one ounce of olive oil is often useful. The child should have abundance of out-door exercise and a free diet, avoiding uncooked vegetables, fruit, sweets \&c. and anything likely to produce catarrh or increase the mucus. 'The patient should be isolated during the period the oxyurides are being expelled, kept from school, should sleep alone and not be allowed to mingle with other children. This treatment should be maintained until all signs of oxyurides are obliterated.

Colchester.

Sports In AID of the London Hospitals. A meeting was held on Dec. 30th, at the offices of the Hospital Saturday Fund in Farringdon-road, in furtherance of the proposed athletic and cycling sports in aid of the hospitals of the metropolis. The chief business was the election of a council, from which a practicable committee will be chosen to carry out the idea.

Fatal Football Castalty.-On the 3rd inst. an inquest was held at Durham on the body of a football player who suffered fatal injuries in a match played in October last. It appeared that the injury was sustained by the deceased coming into violent collision with another player, causing fracture of the spine.

\section{de dittror}

\section{HOSPITAL PRACTICE。 BRITISH AND FOREIGN.}

Nulla autem est alia pro certo noscendi via, nisi quamplurimas et morborum et dissectionum historias, tum aliorum tum proprias collectas habere, et inter se comparare.-MorgagNi De Sed. et Caus. Morb., ib. iv. Procmium.

\section{ROYAL HOSPITAL FOR CHILDREN AND WOMEN, WATERLOO BRIDGE ROAD.}

CONGENITAL CYSTIC HYGROM OF NECK TREATED BY DISSECTION $\Lambda$ ND IODINE.

(Under the care of Mr. Marmaduke Shgild.)

THrs case is a very typical one of those congenital cervical cysts to which the names "cystic hygroma" and "hydrocele of neck" have been applied. The affection has been fully described in this country among other's by Mr. T. Smith, Mr. Birkett and Mr. Holmes. This case forcibly illustrates, what was especially pointed out by Mr. Holmes, that, however superficial they may appear, the major part of these cystic growths invariably extends beneath the deep fascia, the superficial cysts being merely hernial protrusions which have likely enough found their way through the deep fascia by pressure. The free extension of this cyst by large loculi beneath the deep fascia, reaching towards the base of the skull and hyoid bone, is worthy of attention in relation to the theory propounded by Mr. Sutton, that these cysts may be representative of the laryngeal saccules of certain monkeys. The amount of soft, vascular, intra-cystic growth in this case was remarkable, and when fungation occurred from inflammation caused by the iodine it was indeed difficult to believe that the growth was not of a malignant nature. As is well known, all kinds of treatment have been employed to effect the cure of these cysts. All treatment is risky, for young children ill bear extensive operations and prolonged suppurction. Probably it would be well in the majority to postpone any operative interference until the child has attained the age of puberty; but inflammation of the cysts may compel us to interfere, and so may the importunities of relatives. If the surgeon be well assured that even in the most simplelooking cases he has really a difficult task before him, removal of these growths by dissection is probably the most satisfactory treatment. The superficial cysts can thus be safely removed and the deeper loculi obliterated by drainage and the subsequent inflammatory process. The masses of solid growth, unless easily removed, had better be left intact. They are often very vascular and so incorporated with adjacent structures that safe removal may be out of the question. 'Ihe perilous illness through which a young patient operated upon for congenital cer vical cyst may have to pass is illustrated by the present case. Indeed, had it not been for the care bestowed upon the case by the house surgeon, Mr. Richards, and the employment of excellent nursing, a different result might have occurred. In conclusion, it may be borne in mind that quite a significant number of these cases undergo spontaneous cure by inflammation, suppuration and subsequent shrinkage. This is especially likely to occur when the cyst is of enormous size and liable to injury. Hæmorrhage has also taken place into the cyst cavities with subsequent shrinkage, and the possible communication or close connexion of the cysts with large veins in the neck must not be lost sight of in performing the operation of removal by dissection. For the notes of the case we are indebted to Dr. 'Theodore Fisher, registrar to the hospital.

F. B-, aged one year and seven months, was admitted on Sept. 12th, 1892. History : A swelling in the hinder part of the neck ; present at birth, but is said to have been much smaller at that time. Has twice been tapped by Dr. Daniel of Epsom, who sent the case to Mr. Sheild, the last tapping having been six weeks ago. Clear fluid was drawn off. The swelling has increased considerably in the last six months.

On admission to hospital the child was fairly wellnourished, but pale and delicate looking and of stuntsd 